\title{
PROGRAM PENGUATAN LEMBAGA DISTRIBUSI PANGAN MASYARAKAT (P-LDPM) TERHADAP KINERJA GAPOKTAN DI KECAMATAN BEKRI KABUPATEN LAMPUNG TENGAH
}

\author{
(Program for Strengthening Community Food Distribution Institution (P-LDPM) and the Performance of \\ Farmer Groups in Bekri Subdistrict Lampung Tengah District)
}

Agustya Ratna Pratiwi, Serly Silvianti, Rio Tedi Prayitno

Jurusan Agribisnis, Fakultas Pertanian, Universitas Lampung, Jl. Prof. Dr. Soemantri Brojonegoro No.1 Bandar Lampung 35141, Telp. 08975786996, e-mail: agustyaratna @ gmail.com

\begin{abstract}
This research aims to analyze the implementation of the P-LDPM and the difference between the performance of program recipient farmer groups and non-recipient. The research is a survey conducted in Bekri District, Lampung Tengah Region, as Bekri is an area chosen by government as P-LDPM receiver. Respondents are organizers of farmer groups chosen purposively by consideration that the organizers are the people who receive the program directly. The research data are collected in January - February 2018 and analyzed by quantitative descriptive analysis method. The results showed that implementation of the P-LDPM was started in 2013, which known by the donation from government amounted Rp150,000,000.00. The rate of performance of farmer groups recipients of the P-LDPM program was as high categorized. Meanwhile, the rate of performance of farmer groups that do not receive the program was in a medium category. $P$ LDPM had significant impacts on the rate of performance of farmer groups.
\end{abstract}

Key words: farmer groups combined, performance, P-LDPM

\section{PENDAHULUAN}

Indonesia merupakan negara agraris, dengan sebagian besar penduduknya bekerja di sektor pertanian. Sektor pertanian ini diharapkan mampu mencukupi kebutuhan pangan masyarakat Indonesia secara merata. Jumlah pertumbuhan penduduk Indonesia yang sangat besar, ditambah berkurangnya lahan pertanian yang telah dikonversi menjadi pemukiman dan lahan industri, menjadikan pangan menjadi salah satu komoditas yang penting bagi bangsa Indonesia.

Menurut Undang-Undang Republik Indonesia Nomor 18 tahun 2012, pangan merupakan kebutuhan dasar manusia yang paling utama sebagai komponen dasar untuk mewujudkan sumber daya manusia yang berkualitas. Pada dasarnya, konsep ketahanan pangan lebih luas dibandingkan konsep swasembada pangan, yakni mencakup tiga unsur pokok yang meliputi ketersediaan pangan, distribusi, dan konsumsi. Upaya pengembangan di sektor pertanian khususnya tanaman pangan masih dihadapkan pada berbagai masalah, seperti sulitnya petani atau pelaku usaha tani untuk memperoleh bantuan untuk pembiayaan bagi kelangsungan usaha tani yang mereka lakukan. Selain itu, harga produk pertanian yang fluktuatif dan rendah pada saat panen menjadi masalah pula. Akses untuk sumber pembiayaan yang diperoleh melalui perbankan atau lembaga keuangan non bank dirasakan sulit untuk dipenuhi oleh petani.

Permasalahan yang telah disebutkan di atas, mendorong pemerintah meluncurkan suatu program untuk memberikan perlindungan dan pemberdayaan petani, kelompok tani, maupun gabungan kelompok tani. Pada tahun 2009, Kementerian Pertanian yang diwakili oleh Badan Ketahanan Pangan telah melaksanakan kegiatan atau Program Penguatan Lembaga Distribusi Pangan Masyarakat (P-LDPM).

Penguatan Lembaga Distribusi Pangan Masyarakat (P-LDPM) adalah kegiatan pemberdayaan gapoktan dalam rangka meningkatkan kemampuan unit usaha yang dikelolanya yaitu melalui pengembangan unit-unit usaha distribusi atau pemasaran atau pengolahan dan pengelolaan cadangan pangan serta pembangunan sarana penyimpanan, sehingga dapat meningkatkan posisi tawar petani, meningkatkan nilai tambah produksi petani dan mendekatkan akses terhadap sumber 
pangan (Badan Ketahanan Pangan 2015). Dana bantuan sosial disalurkan melalui pendampingan dan pembinaan. Dana tersebut hanya diberikan kepada gabungan kelompok tani pada tahapan penumbuhan dan pengembangan. Pada tahun ketiga, gabungan kelompok tani hanya akan menerima pembinaan dari pendamping yang dilakukan oleh tim teknis maupum tim pembina.

Provinsi Lampung merupakan salah satu provinsi yang mendapatkan bantuan dana P-LDPM. Terdapat tiga kabupaten yang mendapatkan dana bantuan modal P-LDPM di Provinsi Lampung yaitu Kabupaten Lampung Timur, Kabupaten Lampung Tengah, dan Kabupaten Tanggamus. Kabupaten Lampung Tengah merupakan salah satu kabupaten yang telah melaksanakan P-LDPM pada tahapan mandiri. Selain itu, dari ketiga kecamatan yang ada di Kabupaten Lampung Tengah yaitu Kecamatan Anak Ratu Aji, Kecamatan Sendang Agung, dan Kecamatan Bekri, hanya Kecamatan Bekri yang telah melaksanakan atau menjalankan P-LDPM hingga memasuki tahapan mandiri atau tahap tahun ketiga.

Gapoktan yang telah mencapai tahapan mandiri, diwajibkan mampu bergerak mandiri dan berkelanjutan dalam mengelola unit-unit usahanya, sehingga tidak tergantung kepada bantuan pemerintah. Oleh karena itu, diperlukan adanya penelitian agar dapat diketahui bagaimana pelaksanaan P-LDPM, tingkat kinerja gapoktan penerima P-LDPM dan gapoktan non P-LDPM, serta dampaknya terhadap petani di Kecamatan Bekri dengan cara membandingkan dua gapoktan yang mendapatkan dana bantuan P-LDPM dan gapoktan yang tidak mendapatkan dana bantuan P-LDPM. Berdasarkan uraian tersebut, maka tujuan dari penelitian ini adalah mengetahui pelaksanaan P-LDPM pada gabungan kelompok tani, tingkat kinerja gapoktan penerima P-LDPM dan kinerja gapoktan non P-LDPM, serta dampak pelaksanaan program P-LDPM terhadap kinerja gabungan kelompok tani.

\section{METODE PENELITIAN}

Metode yang digunakan dalam penelitian ini adalah metode survei. Penelitian dilakukan di Kecamatan Bekri, Kabupaten Lampung Tengah. Pemilihan lokasi dilakukan secara sengaja (purposive), dikarenakan Desa Bangun Sari sudah memasuki tahapan ketiga atau tahapan yang mandiri, sedangkan Desa Rengas yang tidak mendapatkan bantuan dana P-LDPM dan letaknya di sebelah Desa Bangun Sari dipilih sebagai pembanding. Penelitian ini dilakukan pada bulan Januari-Februari 2018.

Data yang digunakan pada penelitian ini adalah data primer dan data sekunder. Data primer didapat dari hasil wawancara dengan menggunakan kuesioner, sedangkan data sekunder didapat dari instansi-instansi terkait dengan penelitian, yaitu Badan Keamanan Pangan Daerah Provinsi Lampung (BKPD), BP3K Kecamatan Bekri, pengurus gapoktan, pengurus dan anggota poktan. Penentuan sampel pada penelitian ini secara sengaja (purposive sampling) yaitu dengan pertimbangan bahwa pengurus merupakan pihak yang menerima langsung dana bantuan, bimbingan dan pendampingan dari P-LDPM.

Responden dalam penelitian ini yaitu pengurus gapoktan berjumlah 6 orang, yang terdiri dari ketua, sekretaris, dan bendahara dari Gapoktan Bangun Tani dan Gapoktan Tani Makmur. Jumlah kelompok tani keseluruhan adalah 34 kelompok. Berdasarkan asumsi analisis U Mann Whitney menyatakan bahwa variabel independen satu dengan yang lain yang berarti data berasal dari kelompok yang tidak berpasangan, maka jumlah keseluruhan kelompok tani akan dijadikan sebagai sampel. Oleh karena itu, diperoleh jumlah responden yang akan diteliti adalah 102 pengurus kelompok yakni 42 pengurus kelompok tani dari Gapoktan Bangun Tani dan sebanyak 60 pengurus kelompok tani dari Gapoktan Tani Makmur dan 6 pengurus gapoktan. Jadi, total keseluruhan sampel pada penelitian ini adalah 108 responden.

Metode analisis data yang digunakan pada penelitian ini adalah metode deskriptif kuantitatif. Metode analisis deskriptif digunakan untuk analisis pelaksanaan P-LDPM. Untuk menganalisis perbandingan program P-LDPM terhadap kinerja gapoktan menggunakan analisis statistik non parametrik yaitu analisis uji komparatif $U$ Man Whitney, dilihat berdasarkan nilai signifikansi $\mathrm{t}$ hitung.

1. Jika nilai signifikansi $\leq \alpha$ pada $\alpha=0,10$ maka $\mathrm{H}_{1}$ diterima dan $\mathrm{H}_{0}$ ditolak, artinya terdapat perbedaan kinerja antara gapoktan penerima PLDPM dengan gapoktan non P-LDPM.

2. Jika nilai signifikansi $\geq \alpha$ pada $\alpha=0,10$ maka $\mathrm{H}_{1}$ ditolak dan $\mathrm{H}_{0}$ diterima, artinya tidak terdapat perbedaan kinerja antara gapoktan penerima PLDPM dengan gapoktan non PLDPM (Siegel 1997). 


\section{HASIL DAN PEMBAHASAN}

\section{Gambaran Umum Kecamatan Bekri}

Kecamatan Bekri merupakan salah satu kecamatan di Kabupaten Lampung Tengah dengan luas wilayah sebesar $10.552,63$ ha. Terdapat 8 desa pada kecamatan ini yaitu Desa Bangun Sari, Desa Binjai Agung, Desa Goras Jaya, Desa Kedautan, Desa Kesuma Jaya, Desa Kesuma dadi, Desa Rengas dan Desa Sinar Banten. Secara umum, Kecamatan Bekri memiliki iklim tropis sebagaimana iklim Provinsi Lampung pada umumnya dengan curah hujan berkisar antara $2.264 \mathrm{~mm}$ sampai dengan $2.868 \mathrm{~mm}$. Suhu udara di Kecamatan Bekri berkisar antara $20^{\circ} \mathrm{C}$ hingga $33^{\circ} \mathrm{C}$. Bentuk wilayah Kecamatan Bekri yakni 90 persen merupakan dataran berombak dan 10 persen berbukit (BPS Lampung Tengah 2017).

\section{Gambaran Umum Gapoktan Bangun Tani}

Gapoktan Bangun Tani merupakan gabungan dari beberapa kelompok tani yang ada di Desa Bangun Sari. Desa ini menjadi satu-satunya desa di Kecamatan Bekri yang mendapatkan bantuan dana dari P-LDPM. Potensi pertanian seperti tanaman pangan dan sayuran di Desa Bangun Sari cukup tinggi, namun tanaman padi menjadi tanaman yang paling dominan ditanam di desa ini. Meskipun produktivitas padi di Desa Bangun Sari tidak sebanyak produktivitas desa lainnya, namun kondisi ketersediaan pangan petani-petani di desa ini selalu tercukupi.

\section{Gambaran Umum Gapoktan Tani Makmur}

Gapoktan Tani Makmur merupakan gabungan dari beberapa kelompok tani yang ada di Desa Rengas. Desa Rengas merupakan desa yang memiliki lahan persawahan terluas dibandingkan desa lainnya di Kecamatan Bekri. Mayoritas petani di desa ini memilih untuk bercocok tanaman pangan seperti padi dan ubi kayu, ketimbang menggunakan lahannya untuk ladang atau perkebunan. Oleh karena itu, Desa Rengas menjadi daerah penyumbang padi terbesar untuk Kecamatan Bekri, yakni sekitar 5.778,09 ton (BPS Lampung Tengah 2017).

\section{Karakteristik Gapoktan}

Karakteristik Gapoktan Bangun Tani dan Gapoktan Tani Makmur memiliki karakteristik yang hampir sama. Jenis tanaman yang ditanam kedua gapoktan ini sama-sama tanaman pangan.
Gapoktan Bangun Tani didominasi oleh tanaman padi dan sayuran, sedangkan Gapoktan Tani Makmur didominasi oleh tanaman padi dan ubi kayu. Dibandingkan dengan gapoktan lainnya, Gapoktan Tani Makmur menjadi daerah penyumbang padi terbesar untuk Kecamatan Bekri, yakni sekitar 5.778,09 ton (BPS Lampung Tengah 2017).

Dalam hal unit usaha, Gapoktan Bangun Tani memiliki lima unit usaha yakni unit usaha sarana produksi, unit usaha simpan pinjam, unit usaha ilmu dan teknologi, unit usaha pengelolaan cadangan pangan, unit usaha distribusi, pemasaran dan unit usaha pemasaran dan kerjasama. Berbeda dengan Gapoktan Bangun Tani, Gapoktan Tani Makmur hanya mempunyai empat unit usaha untuk kepengurusan periode ini, antara lain unit usaha simpan pinjam, unit usaha ilmu dan teknologi, unit usaha sarana produksi, dan unit usaha distribusi pemasaran.

Selanjutnya, untuk pertemuan atau rapat yang diadakan oleh kedua gapoktan ini cukup berbeda. Pada Gapoktan Bangun Tani, pertemuan diadakan tiga sampai empat kali dalam sebulan. Dua pertemuan wajib diadakan untuk membahas pelaksanaan dan pencapaian program, sedangkan pertemuan selanjutnya diadakan tergantung ada atau tidaknya program-program, permasalahan atau kegiatan-kegiatan yang akan dilaksanakan pada saat itu. Pada Gapoktan Tani Makmur, pertemuan antara anggota dan pengurus dilakukan dua kali dalam sebulan, biasanya dilaksanakan setiap awal dan akhir bulan. Meskipun intensitasnya berbeda, kedua gapoktan ini memiliki tujuan yang sama ketika mengadakan pertemuan, yakni untuk membahas permasalahan transparansi dana, jalannya kegiatan dalam gapoktan, sekaligus mempererat tali silaturahmi antarsesama petani anggota.

Pada waktu diadakannya penelitian, hanya Gapoktan Bangun Tani yang mendapatkan bantuan pemerintah yakni dari program P-LDPM. Bantuan tersebut diberikan dalam bentuk dana bantuan sosial dan pembinaan oleh penyuluh pendamping. Program yang dijalankan oleh gapoktan telah mencapai tahap ketiga atau tahap kemandirian. Lain halnya dengan Gapoktan Tani Makmur, saat ini Gapoktan Tani Makmur tidak sedang menerima bantuan jenis jangka waktu panjang apapun dari pemerintah. Namun sebelumnya, gapoktan ini pernah mendapatkan bantuan PUAP dari pemerintah. Hanya saja, dikarenakan adanya indikasi kecurangan dari oknum pengurus dan 
ketidakaktifan anggota menyebabkan dana yang didapatkan dari bantuan tersebut tidak jelas pemakaiannya, begitu pula dimana dan berapa sisa dana yang tidak digunakan.

\section{Pelaksanaan P-LDPM pada Gapoktan}

Penguatan - Lembaga Distribusi Pangan Masyarakat (P-LDPM) merupakan salah satu kegiatan strategis Badan Ketahanan Pangan di bawah Kementerian Pertanian yang bertujuan untuk meningkatkan kemampuan gapoktan dan unit-unit usaha yang dikelolanya (distribusi, pemasaran dan cadangan pangan) dalam usaha memupuk cadangan pangan dan memupuk modal dari usahanya dan dari anggotanya yang tergabung dalam wadah gapoktan. Gapoktan Bangun Tani menjadi salah satu gapoktan yang mendapatkan bantuan P-LDPM di Kecamatan Bekri. Pada tahun-tahun sebelumnya, gapoktan ini pernah mendapatkan dana bantuan dari program PUAP. Kepengurusan yang efektif, transparan dan adanya kerjasama yang baik dengan anggota, membuat gapoktan ini memanfaatkan dana bantuan tersebut dengan tepat. Hal ini pulalah yang menjadi salah satu penilaian hingga Gapoktan Bangun Tani terpilih sebagai penerima dana dari program $\mathrm{P}$ LDPM.

Inti pokok pelaksanaan P-LDPM adalah terkait dengan mekanisme pemberian dana bantuan sosial dan pendampingan serta realisasi pemberian dana bantuan sosial dan pelaksanaan pendampingan. Pada tahun 2013, melalui bendahara, Gapoktan Bangun Tani menerima bantuan dana sebesar Rp150.000.000,00 yang menandakan bahwa gapoktan ini telah secara resmi memasuki tahap penumbuhan atau tahap pertama dari tiga tahapan program P-LDPM. Sesuai yang diharapkan dari tahap penumbuhan atau tahap pertama, dana bantuan yang diberikan oleh P-LDPM telah dimanfaatkan dengan baik, sehingga telah berhasil membangun satu gudang penyimpanan cadangan pangan semi permanen milik gapoktan. Saat itu, gapoktan juga sudah mampu menyediakan cadangan pangan, ketika terjadi kekurangan pangan. Namun, sayangnya masih terbatas untuk para pengurus saja, dikarenakan stok cadangan pangan masih belum tersedia dalam jumlah besar.

Pada tahap selanjutnya, yakni tahap pengembangan, Gapoktan Bangun Tani diberi dana tambahan sebesar Rp75.000.000,00. Dana tersebut digunakan untuk terus menyempurnakan gudang penyimpanan hingga terbentuklah gudang cadangan pangan permanen dengan kapasitas penyimpanan yang lebih besar. Kapasitas gudang penyimpanan yang dimiliki oleh gapoktan mampu menampung sejumlah kurang lebih 10.000 GKG. Meningkatnya kapasitas gudang penyimpanan, membuat gapoktan mampu menyediakan cadangan pangan tidak hanya untuk pengurus, namun juga anggota. Selain itu, pengurus gapoktan juga menggunakan dana bantuan untuk membeli beberapa hasil panen gabah atau beras dari petani anggota dan membantu petani anggota untuk memasarkan hasil panennya. Hasil yang didapatkan oleh petani pun cukup menguntungkan, sehingga pendapatan petani pun perlahan-lahan mulai meningkat. Hal ini sesuai dengan penelitian Wijaya dan Sudibia (2016) bahwa P-LDPM sangat efektif dalam meningkatkan kesejahteraan para petani. Pendapatan petani terbukti mengalami kenaikan, dikarenakan harga jual gabah yang meningkat setelah dilaksanakannya P-LDPM.

Selama pelaksanaan P-LDPM, para pengurus Gapoktan Bangun Tani maupun pengurus dari masing-masing unit usaha senantiasa diarahkan, agar terus aktif dan secara rutin melakukan pembukuan mengenai pendanaan, pencatatan ketika diadakannya pertemuan, pemantauan jalannya program P-LDPM, serta pelaporan jika ditemukan suatu kendala dan permasalahan yang dihadapi. Sampai saat diadakannya penelitian, Gapoktan Bangun Tani sudah hampir mencapai tahap kemandirian.

Selain dana bantuan sosial, P-LDPM juga memberikan bantuan dalam bentuk pendampingan. Kegiatan P-LDPM dilaksanakan melalui pendekatan pemberdayaan dengan menunjuk satu Petugas Penyuluh Lapang (PPL) dari BP3K untuk mendampingi gapoktan selama jalannya program. Kriteria pendamping yang ditunjuk, yakni:

1. Penyuluh Pertanian atau Petugas Lapangan yang diutamakan berpengalaman di bidang penyuluhan pertanian.

2. Sanggup melaksanakan tugas hingga akhir tahun pelaksanaan dan bertanggung jawab untuk mendampingi dan membimbing Gapoktan secara rutin dengan menandatangani pakta integritas.

3. Pendamping diutamakan berdomisili di desa lokasi penerima kegiatan P-LDPM atau di desa lain di wilayah Balai Penyuluhan Pertanian, Perikanan dan Kehutanan (BP3K) atau kelembagaan penyuluhan di kecamatan.

Pertemuan dengan PPL dilakukan secara fleksibel yakni 2 kali dalam seminggu, tergantung kesepakatan antara pengurus gapoktan dan petugas 
tersebut. Melalui PPL, gapoktan dibina dan dibimbing, agar melalui unit usaha yang dikelolanya mampu mengatasi permasalahan petani anggotanya, khususnya masalah ketidakmampuan anggotanya dalam mengakses pangan di saat paceklik, masalah harga pangan yang jatuh saat panen raya, dan masalah pembiayaan atau modal usaha. Pada penelitian Santi (2016) yang berjudul tingkat kinerja penyuluh pertanian tanaman pangan di BP3K Kecamatan Gadingrejo Kabupaten Pringsewu menyebutkan bahwa penyuluh pertanian harus melakukan penyebaran materi penyuluhan sesuai dengan kebutuhan petani, menerapkan metode penyuluhan dengan kunjungan atau tatap muka, dalam bentuk demonstrasi, temu lapang, temu wicara, temu teknis, temu karya, dan temu usaha, serta melaksanakan penerapan metode penyuluhan dalam bentuk kursus.

\section{Tingkat Kinerja Gapoktan P-LDPM dan Gapoktan Non P-LDPM}

Berdasarkan penelitian Agus (2017) yang berjudul kinerja dan pendapatan rumah tangga anggota kelompok tani nanas di Desa Astomulyo Kecamatan Punggur Kabupaten Lampung Tengah menyimpulkan bahwa tingkat kinerja anggota kelompok tani di Desa Astomulyo Kecamatan Punggur berada pada tingkat klasifikasi tinggi.

Pada penelitian ini kinerja yang dilihat adalah kinerja dari gabungan kelompok tani, yang dihitung dengan cara scoring. Pencapaian kinerja gapoktan ditentukan oleh beberapa indikator yang digunakan untuk menentukan keberhasilan kinerja tersebut, antara lain pengembangan sarana penyimpanan, penyediaan cadangan pangan, dan stabilisasi harga. Rekapitulasi indikator pengembangan sarana penyimpanan dan penyediaan cadangan pangan pada kinerja gapoktan dapat dilihat pada Tabel 1.

Pengembangan sarana penyimpanan dinilai berdasarkan keberadaan gudang penyimpanan, kesesuaian gudang penyimpanan dengan kebutuhan anggota gapoktan, pemanfaatan gudang oleh anggota gapoktan, kapasitas gudang penyimpanan, jumlah gabah yang disimpan dalam gudang, dan dimana anggota gapoktan menyimpan cadangan pangan. Pada indikator pengembangan sarana penyimpanan, didapatkan interval untuk kategori rendah sebesar 7,00-10,70; interval untuk kategori sedang sebesar 10,80-14,50; dan interval untuk kategori tinggi sebesar 14,60-15,30.
Tabel 1. Rekapitulasi indikator pengembangan sarana penyimpanan dan penyediaan cadangan pangan pada kinerja gapoktan di Kecamatan Bekri

\begin{tabular}{|c|c|c|c|c|c|}
\hline \multirow[b]{2}{*}{ No. } & \multirow{2}{*}{$\begin{array}{l}\text { Kinerja } \\
\text { Gapoktan }\end{array}$} & \multicolumn{2}{|c|}{ Skor Rata-Rata } & \multicolumn{2}{|c|}{ Klasifikasi } \\
\hline & & P-LDPM & $\begin{array}{c}\text { Non } \\
\text { P-LDPM }\end{array}$ & P-LDPM & $\begin{array}{c}\text { Non } \\
\text { P-LDPM }\end{array}$ \\
\hline $\begin{array}{r}1.1 \\
1 \\
1\end{array}$ & $\begin{array}{l}\text { Pengembangan } \\
\text { Sarana } \\
\text { Penyimpanan }\end{array}$ & 16,27 & 13,35 & Tinggi & Sedang \\
\hline $\begin{array}{ll}2 . & 1 \\
& \\
& 1\end{array}$ & $\begin{array}{l}\text { Penyediaan } \\
\text { Cadangan } \\
\text { Pangan } \\
\end{array}$ & 13,08 & 10,61 & Tinggi & Sedang \\
\hline
\end{tabular}

Berdasarkan Tabel 1, diketahui bahwa skor ratarata indikator pengembangan sarana penyimpanan dari Gapoktan Bangun Tani adalah 16,27 maka hal ini menunjukkan bahwa tingkat kinerja gapoktan penerima P-LDPM termasuk dalam klasifikasi tinggi. Skor rata-rata indikator pengembangan sarana penyimpanan dari Gapoktan Tani Makmur adalah 13,35 maka tingkat kinerja gapoktan non PLDPM untuk indikator pengembangan sarana penyimpanan termasuk dalam klasifikasi sedang.

Indikator untuk penyimpanan cadangan pangan antara lain dilihat dari ketersediaan cadangan pangan, jumlah pangan yang tersedia di gudang penyimpanan, kapasitas cadangan pangan, jumlah anggota yang memanfaatkan cadangan pangan dan akses anggota Gapoktan Bangun Tani dan Gapoktan Tani Makmur dalam mendapatkan cadangan pangan. Pada indikator penyimpanan cadangan pangan ini didapatkan interval untuk kategori rendah sebesar 5,00-8,30; interval untuk kategori sedang sebesar 8,40-11,70; dan interval untuk kategori tinggi sebesar 11,80-15,10.

Pada indikator penyimpanan cadangan pangan, Gapoktan Bangun Tani secara teratur menyisihkan hasil produksinya hingga 15 ton per musim, sehingga baik pengurus dan anggota dapat melakukan usaha tani tanpa dilanda kekhawatiran bila terjadinya gagal panen. Sementara itu, Gapoktan Tani Makmur menyimpan hasil panennya kurang lebih 10 ton per musim, dapat dilihat pada Tabel 2 . 
Tabel 2. Perkembangan penyimpanan cadangan pangan gabah Gapoktan Bangun Tani (P-LDPM) dengan Gapoktan Tani Makmur (non P-LDPM)

\begin{tabular}{lccc}
\hline & $\begin{array}{c}\text { Musim } \\
\text { Pertama } \\
\text { (Ton) }\end{array}$ & $\begin{array}{c}\text { Musim } \\
\text { Kedua } \\
\text { (Ton) }\end{array}$ & $\begin{array}{c}\text { Simpanan } \\
\text { Cadangan } \\
\text { Pangan (Ton) }\end{array}$ \\
\hline $\begin{array}{l}\text { Gapoktan } \\
\text { Bangun Tani } \\
\text { (P-LDPM) }\end{array}$ & 35 & 30 & 15 \\
$\begin{array}{l}\text { Gapoktan Tani } \\
\text { Makmur (Non }\end{array}$ & 20 & 10 & 10 \\
P-LDPM) & & & \\
\hline
\end{tabular}

Terwujudnya ketahanan pangan di tingkat rumah tangga berdasarkan tabel 2, mewujudkan adanya keberhasilan dari Gapoktan Bangun Tani penerima program (P-LDPM) dengan adanya penyimpanan cadangan pangan gabah di Gapoktan Bangun Tani setiap musimnya. Gapoktan Bangun Tani memiliki cadangan pangan yang cukup untuk kebutuhan anggotanya di musim paceklik, sehingga memungkinkan untuk dapat memenuhi kebutuhan anggota bila suatu saat musim paceklik. Musim paceklik biasanya terjadi ketika musim penghujan atau bencana alam seperti banjir ataupun kekeringan, sehingga anggota tidak bisa atau menghambat proses panen. Dengan adanya penyimpanan cadangan gabah ini, gapoktan bisa bertahan disaat musim paceklik. Menurut penelitian Mariyani (2017) yang berjudul ketersediaan pangan dan faktor-faktor yang mempengaruhi ketersediaan pangan rumah tangga petani padi anggota lumbung pangan di Kecamatan Ambarawa Kabupaten Pringsewu menyebutkan bahwa faktor-faktor yang mempengaruhi ketersediaan pangan rumah tangga petani padi anggota lumbung pangan di Kecamatan Ambarawa adalah luas lahan, pendapatan rumah tangga, tingkat pendidikan, dan umur petani.

\section{Stabilisasi Harga}

Stabilisasi harga adalah upaya yang dilakukan oleh pemerintah untuk mempertahankan suatu harga barang atau jasa pada tingkat tertentu yang dilakukan oleh pemerintah pada saat tingkat laju inflasi yang tinggi sebagai upaya di dalam menstabilkan harga barang dan jasa tersebut selama periode tertentu. Kebijaksanaan harga yang diambil biasanya bertujuan untuk melindungi petani khususnya pada saat panen raya dari posisi tawar yang rendah, serta demi menstabilkan perekonomian yang ada. Kebijakan yang diterapkan oleh pemerintah mengenai harga gabah didasarkan pada Harga Pembelian Pemerintah
(HPP), namun realitanya di lapangan terkadang kebijakan tersebut tidak dilaksanakan oleh para pegiat jual beli gabah. Pada penelitian ini, stabilitas harga pangan dinilai berdasarkan fluktuasi harga yang diukur menggunakan Indeks Harga.

Berdasarkan hasil penelitian, indeks harga HPP untuk Gapoktan Bangun Tani selaku gapoktan penerima P-LDPM pada Tahun 2017 adalah sebesar 113,51 persen; yang berarti bahwa HPP mengalami kenaikan sebesar 13,51 persen dari tahun sebelumnya. Selanjutnya, Indeks Harga untuk harga jual dari petani P-LDPM pada tahun 2017 adalah sebesar 124,67; yang berarti harga jual gabah dari petani mengalami kenaikan sebesar 24,67 persen dari tahun sebelumnya. Oleh karena itu, apabila dibandingkan dengan HPP, maka harga jual gabah oleh petani lebih menguntungkan, yakni dengan selisih kenaikan harga sebesar 11,16 persen.

Selanjutnya, untuk Gapoktan Tani Makmur, yakni gapoktan yang tidak mendapatkan P-LDPM, indeks harga HPP pada tahun 2017 adalah sebesar 113,51 persen; yang berarti bahwa HPP mengalami kenaikan sebesar 13,51 persen dari tahun sebelumnya. Kemudian indeks harga untuk harga jual dari petani non P-LDPM pada tahun 2017 adalah sebesar 115,79; yang berarti harga jual gabah dari petani mengalami kenaikan sebesar 15,79 persen dari tahun sebelumnya. Meskipun harga jual gabah oleh petani non P-LDPM lebih menguntungkan, namun selisih kenaikan harga dengan HPP tidak terlalu besar, yakni sekitar 2,28 persen.

Meskipun harga gabah atau beras yang dihasilkan gapoktan penerima P-LDPM terus mengalami kenaikan, namun tidak akan memberatkan bagi pihak konsumen, dikarenakan harga yang ditetapkan masih cukup rendah dari kisaran Harga Eceran Tertinggi (HET) yang ditetapkan oleh pemerintah. Indikator terwujudnya stabilitas harga gabah di wilayah Gapoktan Bangun Tani sangat baik, indikator itu terlihat dengan meningkatnya ekonomi pedesaan dan meningkatnya harga jual hasil panen gapoktan setara atau di atas harga HPP.

Kegiatan P-LDPM ini memberikan hasil yang baik dalam meningkatkan harga jual hasil panen Gapoktan Bangun Tani dan memiliki selisih yang cukup tinggi dibandingkan dengan Gapoktan Tani Makmur non P-LDPM. Harga jual hasil panen sebelum adanya kegiatan P-LDPM ini dirasa cukup berselisih dari harga HPP, karena harga yang 
ditawarkan bersaingan. Dari meningkatnya harga jual hasil panen petani juga dapat meningkatkan perekonomian Gapoktan Bangun Tani. Hal ini sesuai dengan penelitian Selvina (2012) yakni Program P-LDPM memberikan dampak positif bagi gapoktan yang menerima bantuan P-LDPM yaitu : (1) terwujudnya stabilitas harga gabah, ditandai dengan meningkatnya harga penjualan hasil panen dengan lebih tinggi dari HPP. (2) Terwujudnya ketahanan pangan di tingkat rumah tangga petani dicirikan dengan adanya lumbung atau gudang. (3) Meningkatnya pendapatan petani padi dan jagung ditandai dengan terlaksananya kegiatan jual beli dan kerajasama dengan mitra.

Indikator terwujudnya stabilitas harga gabah di wilayah Gapoktan Bangun Tani sangat baik. Indikator itu terlihat dengan meningkatnya ekonomi pedesaan dan meningkatnya harga jual hasil panen gapoktan setara atau di atas harga HPP. Berdasarkan Badan Pusat Statistik (2017), rata-rata harga gabah di tingkat petani Provinsi Lampung pada tahun 2015-2017 yaitu sebesar Rp3.597,00 per kg. Produsen harus membeli gabah di tingkat petani dengan harga minimal Rp3.597,00 per kg harga gabah dikatakan stabil apabila produsen membeli gabah sesuai dengan HPP. Menurut penelitian Saputra, Arifin, dan Kasymir (2014) yang berjudul Kausalitas Harga Beras, Harga Pembelian Pemerintah (HPP) dan Inflasi, serta Efektivitas Kebijakan HPP di Indonesia menyebutkan bahwa kebijakan harga pembelian pemerintah (HPP) di Indonesia belum efektif. HPP di Indonesia masih dipengaruhi oleh harga eceran beras (HEB), dimana hubungan kausalitas yang terjadi antara harga pembelian pemerintah (HGKP dan HGKG) dan HEB adalah satu arah.

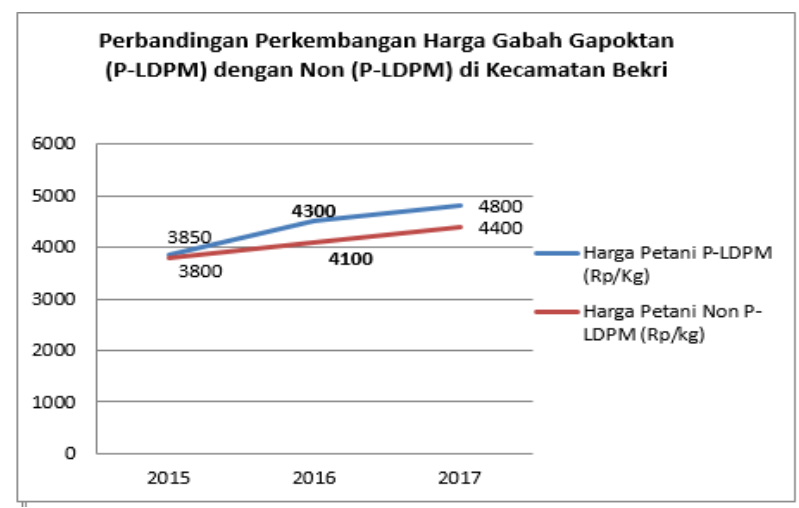

Grafik 1. Perkembangan harga gabah gapoktan Bangun Tani (P-LDPM) dengan gabah Tani Makmur (non P-LDPM)
Jika dilihat pada Grafik 1, perkembangan harga gabah Gapoktan Bangun Tani (P-LDPM) mengalami peningkatan dibandingkan dengan Gapoktan Tani Makmur (non P-LDPM), stabilitas harga gabah Gapoktan Tani Makmur cenderung lebih stabil dan meningkat, sedangkan Gapoktan Tani Makmur tidak mengalami peningkatan, namun stabil. Dilihat dari keuntungan segi produsen Gapoktan Bangun Tani lebih banyak mendapatkan keuntungan dari tahun ke tahun dibandingkan Gapoktan Tani Makmur. Hal ini dikarenakan, pada dasarnya P-LDPM memang ditujukan untuk meningkatkan nilai produksi sekaligus mensejahterakan petani yang tergabung dalam gapoktan.

Kegiatan P-LDPM ini memberikan hasil yang baik dalam meningkatkan harga jual hasil panen Gapoktan Bangun Tani dan memiliki selisih yang cukup tinggi dibandingkan dengan Gapoktan Tani Makmur non P-LDPM. Harga jual hasil panen sebelum adanya kegiatan P-LDPM ini dirasa cukup berselisih dari harga HPP, karena harga yang ditawarkan bersaingan, dari meningkatnya harga jual hasil panen petani juga dapat meningkatkan perekonomian Gapoktan Bangun Tani.

\section{KESIMPULAN}

Kegiatan P-LDPM yang dilakukan Gapoktan Bangun Tani cukup berhasil dalam penerapannya dan mendapat hasil yang positif bagi anggotanya. Perubahan-perubahan atau keberhasilan Gapoktan Bangun Tani (P-LDPM) dibandingkan Gapoktan Tani Makmur (non P-LDPM) tersebut antara lain terwujudnya pengembangan sarana penyimpanan dengan terwujudnya gudang penyimpanan cadangan pangan bagi Gapoktan Bangun Tani dalam satu musim mampu menampung cadangan pangan gabah sebanyak 15 ton per musim, serta terwujudnya stabilitas harga bagi anggota Gapoktan Bangun Tani dalam pembelian gabah hasil panen padi sesuai dengan HPP, bahkan melebihi di atas HPP.

\section{DAFTAR PUSTAKA}

Agus GV. 2017. Kinerja dan pendapatan rumah tangga anggota kelompok tani nanas di Desa Astomulyo Kecamatan Punggur Kabupaten Lampung Tengah. JIIA, 5 (1): http://jurnal. fp.unila.ac.id/index.php/JIA/article/view/1678 /1504. [1 Februari 2017]. 
Badan Ketahanan Pangan. 2015. Pedoman Umum Penguatan Lembaga Distribusi Pangan Masyarakat. Jakarta.

BPS [Badan Pusat Statistik] Kabupaten Lampung Tengah. 2017. Kecamatan Bekri Dalam Angka Tahun 2017. BPS Kecamatan Bekri. Lampung Tengah. [21 Maret 2017].

BPS [Badan Pusat Statistik]. 2017. Rata-rata Harga gabah menurut provinsi dan kelompok kualitas di tingkat petani. BPS Indonesia. Jakarta. [26 Oktober 2017].

Mariyani S. 2014. Ketersediaan pangan dan faktor-faktor yang mempengaruhi ketersediaan pangan rumah tangga petani padi anggota lumbung pangan di Kecamatan Ambarawa Kabupaten Pringsewu. JIIA, 5 (3):http://jurnal.fp.unila.ac.id/index.php/JIA/a rticle/view/1643/1469. [1 Agustus 2017].

Sekretariat Negara Republik Indonesia. 2012. Undang-Undang No 18 Tahun 2012 tentang Pangan. Sekretariat Negara RI. Jakarta.

Santi. 2016. Tingkat kinerja penyuluh pertanian tanaman pangan di BP3K Kecamatan Gadingrejo Kabupaten Pringsewu. JIIA, 4
(3):http://jurnal.fp.unila.ac.id/index.php/JIA/a rticle/view/1506/1360. [3 Agustus 2016]

Saputra A, B Arifin dan E Kasyimir. 2014. Analisis kausalitas harga beras, harga pembelian pemerintah (HPP) dan inflasi serta efektivitas kebijakan HPP di Indonesia. JIIA, 2 (1): http://jurnal.fp.unila.ac.id/index.php/JIA /article/view/557/519. [1 Januari 2014].

Selvina NK. 2012. Dampak kegiatan Penguatan Lembaga Distribusi Pangan Masyarakat (PLDPM) di Desa Mentaras Kecamatan Dukun Kabupaten Gresik. Tesis. Universitas Negeri Surabaya. Surabaya.

Siegel S. 1997. Statistik Non-Parametrik IlmuIlmu Sosial. PT Gramedia Pustaka Utama. Jakarta.

Wijaya G dan IK Sudibia. 2016. Evaluasi pelaksanaan program lembaga distribusi pangan masyarakat (P-LDPM) pada gapoktan di Kabupaten Tabanan (Studi Gapoktan Aseman III di Desa Megati). Jurnal Kependudukan dan Pengembangan Sumber Daya Manusia, l(12)90-100. Universitas Udayana. Bali. [22 Juli 2018]. 